\title{
THE ROLE OF ORGANIZATIONAL JUSTICE AND ORGANIZATIONAL CLIMATE IN DETERMINING ORGANIZATIONAL COMMITMENTS
}

\author{
I Made Edy Sumarya \\ Mahasaraswati University Denpasar, Bali, Indonesia \\ I GA Eka Teja Kusuma, \\ Mahasaraswati University Denpasar Bali, Indonesia \\ I Nengah Suardhika \\ Mahasaraswati University Denpasar Bali, Indonesia \\ DOI: $10.31364 / \mathrm{SCIRJ} / \mathrm{v} 9 . \mathrm{i07.2021.P0721871}$ \\ http://dx.doi.org/10.31364/SCIRJ/v9.i07.2021.P0721871
}

\begin{abstract}
The purpose of this study was to determine the role of organizational justice and organizational climate in determining organizational commitment and its effect on employee performance at the Bali Provincial Inspectorate Office. The sample in this study as many as 83 people carried out by census. Collecting data using a questionnaire. The data analysis technique used SEM-PLS. The results showed that organizational justice had a positive effect on employee performance, organizational climate had no effect on employee performance, organizational commitment had a positive effect on employee performance, organizational justice had no effect on organizational commitment, and organizational climate had a positive effect on organizational commitment.
\end{abstract}

Keywords : organizational justice, organizational climate, organizational commitment, employee performance

\section{INTRODUCTION}

Dessler (2015:3)states that Human Resource Management (HRM) is a process to acquire, train, assess, and compensate employees, and to manage labor relations, health and safety, and matters relating to justice. according to(Sutrisno, 2015:5) Human Resource Management (HRM) is the utilization, development, assessment, provision of remuneration and management of individual members of the organization or group of workers to achieve a performance within the organization.

Factors that are able to influence the performance of an employee are organizational justice, namely when employees feel that employees are treated fairly by the organization in every aspect, employees tend to show more positive attitudes and behavior (Robbins \& Judge, 2009:56). People will compare the ratio between the results of the work that employees do, such as rewards and promotions, with the inputs they provide compared to the same ratio of others. Organizational justice is the overall perception of employees about what is fair in the organization and the environment in which they work, Robbins and Judge (2015). If employees are not treated fairly, the result will be to reduce the output of employees as a natural response to unfair treatment, Iqbal et al., (2017).

Fair treatment felt by employees will be able to improve the performance of the employee towards the organization. This is in accordance with previous empirical studies conducted by Mai \& Thai (2016), Samreen et al., (2018), Faruk et al., (2016), Soomro and Shah (2019), Nurak et al., 2017), who found that organizational justice had a positive effect on employee performance. This proves that fair treatment is what employees expect once they have invested their time and energy in the organization. Organizational justice can improve individual performance, engender civic behavior, good mental health, lower stress levels and better individual attitudes.

Organizations that fail to provide fair treatment will receive negative reactions from their workers, this statement is in accordance with research conducted by (Kholis, 2017; Iqbal et al., 2017; Wang et al., 2010; Warokka et al., 2012; Xiyan et al., 2010) which in their research found that organizational justice has no effect on employee performance. Furthermore, it is also said that the success of an organization, however, can be influenced by the organizational climate.

Previous research that proves that organizational climate can improve employee performance are as follows: Radianto and Sunuharyo, 2017; Full Moon, 2017; Kembuan et al., 2018; Dewi, 2017; Sitorus, 2016) who found that organizational climate has an influence on employee performance, if it is not paid attention to then the organizational climate will have a bad impact on the agency, this is because employees feel uncomfortable at work so they are not enthusiastic in completing work/office tasks. . 
This statement can be proven from previous research conducted by (Pasaribu, 2016; Sabari, 2015; Kusmaningtyas and Priyana, 2012) which found that organizational climate had no effect on employee performance. In addition to the organizational climate, another factor that can affect the performance of an employee is organizational commitment.

The level of commitment, both agency commitments to employees and between employees and agencies is very necessary because through these commitments a professional work climate will be created. The higher the employee's commitment to the organization, the higher the employee's performance. The higher a person's commitment to his duties, the higher the performance that will be produced, which leads to a higher level of assessment.

This opinion is in accordance with previous empirical studies conducted by (Suharto et al., 2019; Winarja et al., 2018; Abdirahman et al., 2018; Lies, 2015; Zefeiti and Mohamad, 2017) which found that organizational commitment affects performance. employee. However, it turns out that there are results from previous research conducted by (Suwibawa et al., 2018; Sutopo, 2018; Renyut et al., 2017; Novita et al., 2016; Indrayanti and Riana, 2016; Sunarso et al., 2016; Andreas and Agustinus, 2017; Koskei et al., 2018) found that organizational commitment has no effect on employee performance or has not been able to maximize employee performance.

These results prove that, in the world of work, an employee's commitment to the organization plays a very important role and often becomes a very important issue. This is so important that the organization dares to include the element of commitment as one of the requirements to hold a position/position offered in the organization. Unfortunately, although this is very common, it is not uncommon for organizations and employees to still not understand the meaning of commitment seriously. Whereas this understanding is very important in order to create conducive working conditions so that the organization can run efficiently and effectively (Shaputra, 2015).

Another factor that can improve organizational justice is organizational commitment. This can be proven from previous research conducted by Swalhi et al., 2017; Ince et al., 2019; Tahir et al., 2019; Friday and Ugwu, 2019; Hanif and Endang, 2018; Khan and Rashid, 2012 which states that organizational justice is significantly positively related to organizational commitment. While the research conducted (Ghaziani et al., 2012) shows that organizational justice has an effect but overall does not have a significant path to organizational commitment. Similar research was also conducted by (Hasan, 2019; Rejeki \& Wulansari, 2015) which showed that justice within the organization did not have a significant effect on organizational commitment.

It is also said that it turns out that organizational climate is able to increase organizational commitment, this can be proven from previous research conducted by Kristianto et al., 2018; Githinji and Gachunga, 2017; Noordin at al., 2010; Swastadiguna and Dewi, 2018) which states that organizational climate has a positive influence on organizational commitment. Intention to leave is indirectly influenced by organizational climate through organizational commitment as a mediating variable (Nanba et al., 2012). However, it turns out that there are still previous studies that conclude that organizational justice is not proven to have an effect on organizational commitment (Lambert et al., 2007).
It is also said that organizational commitment is able to mediate the influence of organizational climate on employee performance, this is in accordance with the study of Kristianto et al., (2018) that organizational commitment is able to mediate the indirect effect of organizational climate on employee performance.

Based on the explanation above where the determinants of the success of an organization can not be separated from the factors of organizational justice, organizational climate, organizational commitment and of course the performance of the employees themselves so that it is also in line with the goals of an agency or organization to realize good governance. Good Governance) is a government that is clean, transparent, accountable, participatory and able to respond to change effectively which of course can be implemented with reliable human resources. Good governance is a very important indicator in realizing the value of effectiveness and efficiency in the cycle of people's economic growth and community progress.

Based on phenomena the above and considering the importance of the role of organizational justice, organizational climate and organizational commitment in improving the performance of an employee, the researchers are interested in conducting research on the role of organizational justice and organizational climate in determining organizational commitment and its influence on employee performance at the Bali Provincial Inspectorate Office. So from this explanation, researchers can determine the position of this research is how efforts are made to improve employee performance based on organizational justice and organizational climate that can be linked to organizational commitment based on organizational justice, organizational climate and organizational commitment, as well as to fill several research gaps were found to confirm the relationship of each variable.

\section{LITERATURE REVIEW}

\section{Goal-Setting Theory}

Goal setting theory or goal setting theoryoriginally proposed by Edwin Locke in the late 1960s. He found that specific and difficult goals led to better task performance than easy goals. Goal setting theory is based on evidence that assumes that goals (ideas for the future; desired states) play an important role in action. Goal setting theory is a model of individuals who want to have goals, choose goals and become motivated to achieve goals (Birnberg in Mahennoko, 2011).

According to this theory, one of the commonly observed characteristics of goal-directed behavior is that the behavior continues until the behavior reaches its completion, once a person starts something (such as a job, a new project), he continues to push until the goal is achieved. This theory also states that individual behavior is governed by one's ideas (thoughts) and intentions. Goals can be viewed as goals or levels of work to be achieved by individuals.Goal setting theoryimplies that an individual is committed to a goal (Robbins, 2008). If an individual is committed to achieving his goals, then this will affect his actions and affect the consequences of his performance. The achievement of the goals/objectives set can be viewed as goals or performance levels to be achieved by individuals. 
Overall, the intention in relation to the goals set, is a strong motivation in realizing its performance. Individuals must have skills, have goals, and receive feedback to assess their performance. Achievement of goals/objectives has an influence on employee behavior and performance within the organization. This theory also explains that goal setting that is challenging (difficult) and measurable results will be able to increase job satisfaction (performance), which is followed by ability and work skills.

This study uses the goal-setting theory proposed by Locke (1968) as the main theory (grand theory). Goal setting theory is a form of motivational theory based on the premise that a person has needs that can be remembered or thought of as certain outcomes or goals that are expected to be achieved (Locke and Bryan, 1968). Setting goals (goal setting) is the management of setting goals or objectives for the success of achieving performance (performance) (Davis, 1981 in Sekaran, 1992). Goal setting theory emphasizes the importance of the relationship between the goals set and the resulting performance. The basic concept is that someone who is able to understand the goals expected by the organization, then that understanding will affect their performance behavior.

Every organization that has set goals that are formulated into a budget plan is easier to achieve its performance targets in accordance with the vision and mission of the organization itself. In some cases, participatory set goals result in superior performance, meaning that individuals will have the best performance when assigned the target task by their superiors (Robbins, 2003).

\section{Discrepancy Theory}

The gap theory (Discrepancy Theory) was coined by Locke 1969, 1976. In this gap theory, Locke (in Wexley Yukl, 2005) suggests that satisfaction or dissatisfaction with a number of aspects of work depends on the difference between what is considered to have been obtained and what is desired should be. The "desirable" number of job characteristics is defined as the minimum amount required to satisfy the existing need. Satisfaction will be obtained when there is no difference between the desired conditions and the conditions obtained. If it turns out that what employees get is greater than what is desired, then the individual will feel more satisfied. Although there is Discrepancy, it is a positive Discrepancy. Otherwise, if there is negative discrepancy where what is obtained is far below the minimum limit, the employee will feel dissatisfied. The greater the perceived shortfall, the greater the employee's dissatisfaction. For example, employees consider opportunities for advancement to be more important than other aspects of work, namely rewards, so that progress for employees can be highly valued for satisfaction rather than rewards. While job dissatisfaction can occur when there is a conflict of interest, namely a mismatch between income and desires. For example, many employees who are paid inappropriately are dissatisfied, or the workspace is too hot. the greater the dissatisfaction felt by the employee. For example, employees consider opportunities for advancement to be more important than other aspects of work, namely rewards, so that progress for employees can be highly valued for satisfaction rather than rewards. While job dissatisfaction can occur when there is a conflict of interest, namely a mismatch between income and desires. For example, many employees who are paid inappropriately are dissatisfied, or the workspace is too hot. the greater the dissatisfaction felt by the employee. For example, employees consider opportunities for advancement to be more important than other aspects of work, namely rewards, so that progress for employees can be highly valued for satisfaction rather than rewards. While job dissatisfaction can occur when there is a conflict of interest, namely a mismatch between income and desires. For example, many employees who are paid inappropriately are dissatisfied, or the workspace is too hot. While job dissatisfaction can occur when there is a conflict of interest, namely a mismatch between income and desires. For example, many employees who are paid inappropriately are dissatisfied, or the workspace is too hot. While job dissatisfaction can occur when there is a conflict of interest, namely a mismatch between income and desires. For example, many employees who are paid inappropriately are dissatisfied, or the workspace is too hot.

KThe conclusion of the gap theory is that this theory explains that employee job satisfaction is measured by knowing the difference between what should be (expectations) and perceived reality (difference between how much of something there should be and how much there is now). desired with the actual conditions of reality, if there is a big difference between the desires and shortcomings that want to be fulfilled with reality, people become dissatisfied But if the desired conditions and the deficiencies to be fulfilled turn out to be in accordance with the reality obtained then he will be satisfied.

Based on the explanation of the two theories above, it can be concluded that, improving the performance of employees is the goal to be achieved by the organization, while the variables of organizational justice, organizational climate, and organizational commitment (as mediating variables) are the determining factors. The higher the determinant, the higher the probability of achieving the goal. And employees will be satisfied if the desired conditions are in accordance with existing conditions. Therefore, the more working conditions that match the expectations of the employee, the higher the level of perceived satisfaction and vice versa, the less the working conditions that match the employee's expectations, the lower the level of perceived satisfaction.

Research on the effect of organizational justice on employee performance has been proven in various previous studies by (Mai and Thai, 2016; Samreen et al., 2018; Faruk et al., 2016; Soomro and Shah, 2019; Nurak et al., 2017). the results of his research indicate that organizational justice has a positive influence on employee performance. This means that, fair treatment is what employees expect after they invest their time and energy in the organization, organizations that fail to provide fair treatment will receive negative reactions from their workers, organizational justice can improve individual performance, giving birth to civic behavior., good mental health, lower stress levels and better individual attitudes.

Research on the influence of organizational climate on employee performance has been proven in various previous studies by (Radianto and Sunuharyo, 2017; Purnama, 2017; Kembuan et al., 2018; Dewi, 2017; Sitorus, 2016). employee performance. This means that the achievement of the performance of the employees themselves can be influenced by various factors, one of which is the organizational climate. A conducive organizational climate will be able to manage the needs of the organization optimally, so as to create an environmental atmosphere that supports the achievement of organizational goals through employee performance which can 
be proven by a significant relationship between organizational climate and employee performance.

Research on the effect of organizational commitment on employee performance has been proven in various previous studies by (Suharto et al., 2019; Winarja et al., 2018; Abdirahman et al., 2018; Krejcie and Morgan, 1970; Lies, 2015; Zefeiti and Mohamad, 2017) the results of his research found that organizational commitment has an influence on employee performance. This means that employee commitment will not grow by itself, there is a significant relationship between commitment and performance, if both high and low organizational commitment will have an impact on: 1) employees; for example on the performance and career development of employees in the organization; 2) Organization; Leaders who are highly committed to the organization will lead to high organizational performance, reduced absenteeism, employee loyalty and so on. The strong link between commitment and performance is due to the desire and readiness of employees in the organization to be empowered by accepting various challenges and responsibilities. Employees who have high commitment feel that they are obliged to stay in the organization because they feel that employees should stay in an organization.

Research on organizational justice on organizational commitment has been proven in various previous studies by (Swalhi et al., 2017; Ince et al., 2019; Tahir et al., 2019; Friday and Ugwu, 2019; Hanif and Endang, 2018; Khan). and Rashid, 2012) the result of the study is that organizational justice is significantly positively related to organizational commitment. This means that every organization should provide proper justice for each of its employees in order to increase employee commitment. Employees will feel obedient to fair treatment from the organization if the policies, procedures and implementation are fair to all employees. Therefore,

Research on the influence of organizational climate on organizational commitment has been proven in various previous studies by (Kristianto et al., 2018; Githinji and Gachunga, 2017; Noordin at al., 2010; Swastadiguna and Dewi, 2018). positive for organizational commitment. This means that organizational climate is also related to performance, organizational effectiveness, productivity, commitment and desire to leave, intention to leave is indirectly influenced by organizational climate through organizational commitment. Employees feel more satisfied which will affect the employee's commitment to the organization and if the employee has a positive experience from the work environment, the employee will stay in the organization longer.

Research on the role of organizational commitment is able to mediate the effect of organizational justice on employee performance. It has been proven in various previous studies conducted by Suliman and Kathairi (2013) that organizational commitment is able to mediate the indirect effect of organizational justice on employee performance.

Research on the role of organizational commitment is able to mediate the influence of organizational climate on employee performance has been proven in various previous studies conducted by Kristianto et al. (2018) that organizational commitment is able to mediate the indirect effect of organizational climate on employee performance.
Hypothesis

Hypothesis 1 (H1) Organizational justice has a positive effect on employee performance.

Hypothesis $2(\mathrm{H} 2)$ Organizational climate has a positive effect on organizational commitment.

Hypothesis 3 (H3) Organizational commitment has a positive effect on employee performance

Hypothesis 4 (H4) Organizational justice has a positive effect on organizational commitment.

Hypothesis 5 (H5) Organizational climate has a positive effect on organizational commitment.

Hypothesis 6 (H6) Organizational commitment mediates the effect of organizational justice on employee performance.

Hypothesis 7 (H7) Organizational commitment mediates the effect of organizational climate on employee performance

\section{RESEARCH METHODS}

This research is a quantitative study using three variables, namely: the independent variable (X) namely organizational justice and organizational climate, the dependent variable (Y2) is employee performance, and the mediating variable is organizational commitment (Y1). The data sources used are primary data (in the form of questionnaires) and secondary data (data obtained from the media and internet sites).

To analyze the effect of each variable using descriptive, inferential analysis techniques and evaluating the goodness of fit PLS model. The reason for choosing this analytical technique is because researchers want to know how big the role of organizational justice and organizational climate in determining organizational commitment and their effect on employee performance at the Bali Provincial Inspectorate Office. The total population and the sample to be used are all employees/PNS at the Bali Provincial Inspectorate Office, totaling 83 (eighty three) employees or called the saturated sample/census.

\section{RESULTS AND DISCUSSION}

\section{Testing the hypothesis}

Table 1 Hypothesis Testing Results

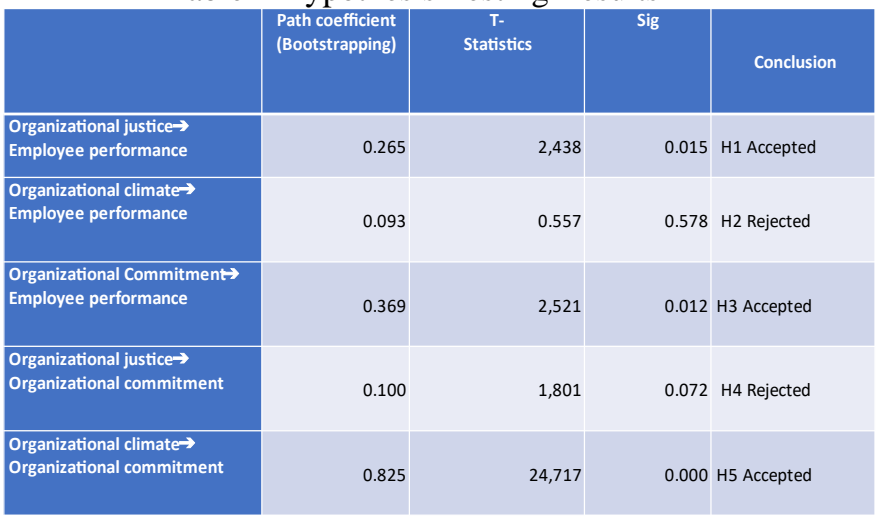

Source: Data processed, 2020 
The results of testing the research hypotheses based on Table 1 are as follows:

1) Testing Hypothesis 1: Organizational justice has a positive effect on employee performance.

These results can be seen in the coefficient value of 0.265 with a t-statistics value of 2.438 . The value of $t-$ statistics is above the value of 1.96 and the value of sig $<0.05$. Based on this, hypothesis 1 is declared accepted.

2) Testing Hypothesis 2: Organizational climate has a positive effect on employee performance.

These results can be seen in the coefficient value of 0.093 with a t-statistics value of 0.557 . The value of $t-$ statistics is below the value of 1.96 and the value of sig> 0.05. Based on this, hypothesis 2 is declared rejected.

3) Testing Hypothesis 3: Organizational commitment has a positive effect on employee performance.

These results can be seen in the coefficient value of 0.369 with a t-statistics value of 2.521 . The value of $t-$ statistics is above the critical value of 1.96 and the value of $\operatorname{sig}<0.05$. Based on this, hypothesis 3 is declared accepted.

4) Testing Hypothesis 4: Organizational justice has a positive effect on organizational commitment.

These results can be seen in the coefficient value of 0.100 with a t-statistics value of 1.801 . The value of $t-$ statistics is below the critical value of 1.96 and the value of sig $>0.05$. Based on this, hypothesis 4 is declared rejected.

5) Testing Hypothesis 5: Organizational climate has a positive effect on organizational commitment.

These results can be seen in the coefficient value of 0.825 with a t-statistics value of 24,717 . The t-statistics value is above the value of 1.96 and the value of sig $<0.05$. Based on this, hypothesis 5 is declared accepted.

\section{Testing Indirect Effects Through Mediation Variables}

In testing the following hypothesis, the mediating role of the organizational commitment variable (Y1) between organizational justice (X1) on employee performance (Y2) and the mediating role of the organizational commitment variable (Y1) between organizational climate (X2) and employee performance (Y2) will be examined. As for the indirect effect hypothesis testing in this study, the results of the analysis can be presented in Table 2 as follows:

\section{Table 2}

Recapitulation of Testing Results of Organizational Commitment Mediation Variables

\begin{tabular}{|c|c|c|c|c|c|c|}
\hline \multirow[t]{2}{*}{ No } & \multirow{2}{*}{$\begin{array}{l}\text { Variable Mediation } \\
\text { Commitment } \\
\text { Organization (Y1) on: }\end{array}$} & \multicolumn{4}{|c|}{ Effect } & \multirow[b]{2}{*}{ Note: } \\
\hline & & (A) & (B) & (C) & (D) & \\
\hline 1 & $\begin{array}{l}\text { Organizational Justice } \\
(\mathrm{X} 1) \rightarrow \text { Employee } \\
\text { performance (Y2) }\end{array}$ & $\begin{array}{l}0.265 \\
\text { (Sig) }\end{array}$ & $\begin{array}{l}0.298 \\
\text { (Sig) }\end{array}$ & $\begin{array}{c}0.037 \\
\text { (Non Sig) }\end{array}$ & $\begin{array}{l}0.369 \\
\text { (Sig) }\end{array}$ & $\begin{array}{c}\text { Full } \\
\text { Mediation }\end{array}$ \\
\hline 2 & $\begin{array}{l}\text { Organizational Climate } \\
\text { (X2) } \\
\rightarrow \text { Employee } \\
\text { Performance } \\
\text { (Y2) }\end{array}$ & $\begin{array}{c}0.093 \\
\text { (Non Sig) }\end{array}$ & $\begin{array}{l}0.419 \\
\text { (Sig) }\end{array}$ & $\begin{array}{l}0.304 \\
(\mathrm{Sig})\end{array}$ & $\begin{array}{c}0.369 \\
(\mathrm{Sig})\end{array}$ & $\begin{array}{c}\text { Full } \\
\text { Mediation }\end{array}$ \\
\hline
\end{tabular}

Source: Data processed, 2020
The information obtained from Table 2 above is the result of testing the mediating variables that can be conveyed as follows:

1) Organizational commitment (Y1) is able to mediate positively and significantly on the indirect effect of organizational justice (X1) on employee performance (Y2) is Full Mediation. This result is shown from the mediation test carried out, it appears that the effects of A, and D have significant values, and the effect of $\mathrm{C}$ is not significant.

2) Other information that can be conveyed, the mediating effect of organizational commitment variable (Y1) on the indirect effect of organizational climate (X2) on employee performance (Y2) is Full Mediation. This finding provides an indication that the mediating variable of organizational commitment (Y1) is proven to be a key determinant of the effect on organizational justice (X1) and organizational climate (X2) on employee performance (Y2).

In order to determine the overall effect for each relationship between the variables studied, a recapitulation of direct effects, indirect effects and total effects can be presented in Table 3 below:

Table 3

Calculation of Direct, Indirect and Total Effects

\begin{tabular}{|c|c|c|c|c|}
\hline No & Variable Relationship & Direct Effect & Indirect Effect & Total Effect \\
\hline 1 & $\begin{array}{l}\text { Organizational justice (X1) } \rightarrow \text { Employee } \\
\text { Performance (Y2) }\end{array}$ & $0.265 \mathrm{~S}$ & $0.037 \mathrm{NS}$ & 0.302 \\
\hline 2 & $\begin{array}{l}\text { Organizational climate }(\mathrm{X} 2) \rightarrow \text { Employee } \\
\text { Performance (Y2) }\end{array}$ & $0.093 \mathrm{NS}$ & $0.304 \mathrm{~S}$ & 0.397 \\
\hline 3 & $\begin{array}{l}\text { Organizational commitment (Y1) } \rightarrow \\
\text { Employee Performance (Y2) }\end{array}$ & $0.369 \mathrm{~S}$ & - & 0.369 \\
\hline 4 & $\begin{array}{ll}\text { Organizational justice } & (\mathrm{X} 1) \rightarrow \\
\text { Organizationalcommitment }(\mathrm{Y} 1) & \end{array}$ & $0.100 \mathrm{NS}$ & - & 0.100 \\
\hline 5 & $\begin{array}{l}\text { Organizational climate } \\
(\mathrm{X} 2) \rightarrow \text { Organizationalcommitment }(\mathrm{Y} 1)\end{array}$ & $0.825 \mathrm{~S}$ & - & 0.825 \\
\hline
\end{tabular}

Description: $\mathrm{S}=$ Significant NS = Not Significant

Source: Data processed, 2020

Information obtained from Table 3 above, the mediating effect of the organizational commitment variable (Y1) on the indirect effect of organizational justice (X1) on employee performance (Y2) is smaller, which is 0.037 compared to the mediating effect of the organizational commitment variable (Y1) on the indirect effect. direct organizational climate (X2) on employee performance (Y2) with the resulting total effect of 0.302 .

Likewise, the mediating effect of the organizational commitment variable (Y1) on the indirect effect of organizational climate $(\mathrm{X} 2)$ on employee performance $(\mathrm{Y} 2)$ is greater, which is 0.304 compared to the mediating effect of the organizational commitment variable (Y1) on the indirect effect of organizational climate (X2) on employee performance (Y2) with the resulting total effect of 0.397 .

This finding provides an indication that higher organizational commitment makes employees improve their work skills in the organization so that later they can improve employee performance which has an impact on the company's progress on an ongoing basis. 


\section{Discussion}

The Effect of Organizational Justice on Employee Performance

The results of hypothesis testing indicate that organizational justice has a positive and significant effect on employee performance. These results mean that the more fair the organization treats its employees, the higher the performance of employees at the Bali Provincial Inspectorate Office. Employees feel fairness in carrying out their duties and work at the Bali Provincial Inspectorate Office if the supervisor's attitude is fair, followed by fairness of promotion opportunities, recognition of hard work, and fairness of performance appraisal procedures. The sense of fairness received by these employees will be able to have a direct impact on their performance, especially on the ability to work together, then punctuality, employee attendance, responsibility, and quantity of work.

The results of this study confirm the results of the studyconducted by Mai \& Thai (2016), Samreen et al. (2018), and Faruk et al. (2016) tang found that organizational justice has a positive influence on employee performance. In addition, the results of this study are in accordance with the findings of Soomro \& Shah (2019) and Nurak et al. (2017) that the fair treatment that employees expect after they have invested their time and energy can be responded well by the organization, thus encouraging them to produce good performance.

Organizational justice at the Bali Provincial Inspectorate Office can be realized and in accordance with the reality of prioritizing a fair superior attitude to employees, so that every employee will feel comfortable feeling himself part of the organization and can work more productively which in turn can improve employee performance. Likewise, fair promotion opportunities, recognition of hard work and fair performance appraisal procedures felt by every employee will be able to improve employee performance.

The sense of fairness received by employees will later determine the achievement of their work, especially on promotion opportunities, recognition of hard work, assessment procedures for subordinates, and fair superiors' attitudes towards subordinates in an effort to influence and move employees to fight for the vision and mission of the organization so that the goals of the Office Bali Provincial Inspectorate.

\section{The Effect of Organizational Climate on Employee Performance}

The results of hypothesis testing indicate that organizational climate has no effect on employee performance. These results mean that the increase or decrease in employee performance cannot be determined from the influence of the ups and downs of the organizational climate at the Bali Provincial Inspectorate Office and cannot be formed from organizational climate indicators. This study proves that changes in organizational climate increase and decrease cannot cause changes in employee performance at the Bali Provincial Inspectorate Office. The knowledge possessed, honesty, keeping promises, employee appearance, atmosphere for service, and location comfort are still deemed not good so that they cannot have an impact on improving organizational performance on the aspect of timeliness of completion of work and responsibilities borne by employees.
The results of this study contradict the results of research conducted by Radianto and Sunuharyo, 2017; Full Moon, 2017; Kembuan et al., 2018; Dewi, 2017; Sitorus, 2016, which states that organizational climate has an influence on employee performance.

\section{The Effect of Organizational Commitment on Employee Performance}

The results of hypothesis testing indicate that organizational commitment has a positive and significant effect on employee performance. This result means that the increasing organizational commitment felt by employees at the Bali Provincial Inspectorate Office, then the employee's performance will increase. Increased organizational commitment felt by employees will have a direct impact on improving employee performance. Increased organizational commitment is shown through a sense of belonging, because the sense of belonging to employees will be able to provide a better boost to employee performance. Loyalty and sincere dedication from employees will be able to provide a higher impetus to employee performance,

The results of this study are the same as those of Suharto et al., 2019; Winarja et al., 2018; Abdirahman et al., 2018; Krejcie and Morgan, 1970; Lies, 2015; Zefeiti and Mohamad, 2017) which states that organizational commitment has an influence on employee performance. This means that, employee commitment will not grow by itself, there is a significant relationship between commitment and performance, if both high and low organizational commitment will have an impact on: 1) employees; for example on the performance and career development of employees in the organization; 2) Organization; Leaders who are highly committed to the organization will lead to high organizational performance, reduced absenteeism, employee loyalty and so on. The strong link between commitment and performance is due to the desire and readiness of employees in the organization to be empowered by accepting various challenges and responsibilities. Employees who have high commitment feel that they are obliged to stay in the organization because they feel that employees should stay in an organization.

When the perceived organizational commitment increases by employees, the performance also increases. Conversely, if the perceived organizational commitment of employees decreases, the performance will decrease.

Employees at the Bali Provincial Inspectorate Office give a high perception of organizational commitment through indicators of a sense of belonging, because the sense of belonging that employees have will be able to provide a better boost to employee performance. Loyalty and sincere dedication from employees will be able to provide a higher impetus to employee performance, as well as being part of a better organization and integrity will be able to provide a better influence on employee performance.

\section{The Effect of Organizational Justice on Organizational Commitment}

The results of the hypothesis test indicate that organizational justice has no effect on organizational commitment at the Bali Provincial Inspectorate Office. These results mean that the increase or decrease in organizational commitment cannot be determined from the influence of the ups and downs of organizational justice at the Bali Provincial Inspectorate Office. This study proves that changes in 
organizational justice increase and decrease cannot cause changes in organizational commitment. There are still employees at the Bali Provincial Inspectorate Office who give a very low perception of the recognition of hard work that is still very low so that employees are not sure of their commitment to the organization. Likewise, there are still some employees who give very low perceptions of the work appraisal procedure indicators,

The results of this study have refuted various studies conducted by Swalhi et al., 2017; Ince et al., 2019; Tahir et al., 2019; Friday and Ugwu, 2019; Hanif and Endang, 2018; Khan and Rashid, 2012 which states that organizational justice is significantly positively related to organizational commitment.

Organizational justice at the Bali Provincial Inspectorate Office cannot be realized and is not in accordance with the reality that prioritizes a fair superior attitude to employees, so that every employee will feel comfortable feeling himself part of the organization and can work more productively which in turn can improve employee performance. Likewise, fair promotion opportunities, recognition of hard work and fair performance appraisal procedures that are felt by every employee cannot improve employee performance.

The Influence of Organizational Climate on Organizational Commitment

The results of hypothesis testing indicate that organizational climate has a positive and significant effect on employee performance at the Bali Provincial Inspectorate Office. This means that the better the organizational climate felt by employees, the organizational commitment given by employees to the company will increase.

Employees feel the organizational climate at the Bali Provincial Inspectorate Office if the knowledge possessed, honesty, keeping promises, appearance of employees, atmosphere for service, and comfortable location are felt to be very good can have an impact on increasing organizational commitment.

Employees at the Bali Provincial Inspectorate Office give a high perception of the organizational climate through the belief given in easy-to-understand language, an atmosphere for service, knowledge and location convenience, so that every employee will feel comfortable in carrying out their duties and obligations which in the end can realize organizational commitment. . Another thing that employees feel is getting better at carrying out their duties and obligations is the existence of training for employees, so that employees can get better supplies and knowledge in carrying out their duties and obligations, as well as the appearance of employees and the latest equipment is considered to provide better organizational commitment .

This study confirms the same results as the research conducted by Kristianto et al., 2018; Githinji and Gachunga, 2017; Noordin at al., 2010; Swastadiguna and Dewi, 2018) which states that organizational climate has a positive influence on organizational commitment. This means that organizational climate is also related to employee performance the results of the work of employees both in quantity and quality, timeliness, employee attendance or absenteeism and the ability to work together which are indirectly influenced by the organizational climate through organizational commitment. Employees feel more satisfied which will affect the employee's commitment to the organization and if the employee has a positive experience from the work environment, the employee will last longer in the organization, so the better the organizational climate is perceived by employees, the stronger the commitment to the organization.

The results of this analysis indicate that organizational climate indicators have succeeded in increasing organizational commitment through indicators of increasing knowledge, employee training, preparation in carrying out tasks, use of new equipment, consistency of service performance, language that is easy to understand, and honesty can influence and move employees in fighting for goals. organization so that it can be realized so that organizational commitment can increase. Similarly, the employees have given a positive response through the perception given to the organizational climate at the Bali Provincial Inspectorate Office.

The Role of Organizational Commitment in Mediating the Effect of Organizational Justice on Employee Performance

The results of the hypothesis test show that Organizational commitment is able to mediate positively and significantly on the indirect effect of organizational justice on employee performance in Bali Provincial Inspectorate Office. These results mean that organizational commitment is owned by employees through a sense of belonging, because the sense of belonging that exists among employees will be able to have an influence on organizational justice, so that increasing organizational justice along with organizational commitment can create changes in employee performance.in Bali Provincial Inspectorate Office. The results of this study are in line with researchers conducted by Suliman and Kathairi (2013) who stated that organizational commitment is able to mediate the effect of organizational justice on employee performance.

The results of this study mean that the role of the indicators used in organizational commitment has been able to improve organizational justice on the performance of employees at the Bali Provincial Inspectorate Office. The more fair the leader of the organization to his subordinates will automatically foster a high sense of commitment by the employee to the organization where they work so that it will be able to improve the performance of the employee.

The mediating effect of organizational commitment on this indirect effect is partial (full mediation). In other words, the implementation of organizational commitment can be said to be the main determinant of the indirect effect of organizational justice on employee performance.

\section{The Role of Organizational Commitment in Mediating the} Effect of Organizational Climate on Employee Performance

The results of the hypothesis test show that mediating effect of organizational commitment variable on the indirect effect of organizational climate on employee performance in Bali Provincial Inspectorate Office. This result means that the organizational commitment possessed by employees through a sense of belonging, because the sense of belonging that exists in employees will be able to provide a better impetus for a healthier organizational climate, so that improving the organizational climate along with organizational commitment can create changes in employee performance.in Bali Provincial Inspectorate Office. The results of this study are in line with the researchers conducted by Kristianto et al,. (2018) that organizational commitment is able to mediate the indirect effect of organizational climate on employee performance. 
This finding provides an indication that all indicators of organizational commitment mediating variables in this study have proven to be key determinants of the influence on organizational justice and organizational climate on employee performance at the Bali Provincial Inspectorate Office. The higher organizational commitment makes employees increasingly improve their work abilities in the organization so that later they can improve employee performance which has an impact on the continuous progress of the organization.

The mediating effect of organizational commitment on this indirect effect is partial (full mediation). In other words, the implementation of organizational commitment can be said to be the main determinant of the indirect effect of organizational climate on employee performance.

\section{CONCLUSIONS AND SUGGESTIONS}

\section{Conclusions}

Based on the discussion of the research results, it can be concluded that the influence of organizational justice and organizational climate in determining organizational commitment and their effect on employee performance at the Bali Provincial Inspectorate Office are as follows.

1. Organizational justice has a positive and significant effect on employee performance at the Bali Provincial Inspectorate Office. This result means that the better the organizational justice, the higher the performance of the employees at the Bali Provincial Inspectorate Office.

2. Organizational climate has no effect on employee performance at the Bali Provincial Inspectorate Office. This means that the increase or decrease in employee performance does not depend on the organizational climate at the Bali Provincial Inspectorate Office.

3. Organizational commitment has a positive effect on employee performance at the Bali Provincial Inspectorate Office. This means that the better the organizational commitment, the better the employee's performance. at the Bali Provincial Inspectorate Office.

4. Organizational justice has no effect on organizational commitment at the Bali Provincial Inspectorate Office. This means that the increase or decrease in organizational commitment at the Bali Provincial Inspectorate Office does not depend on organizational justice.

5. Organizational climate has a positive effect on organizational commitment at the Bali Provincial Inspectorate Office. This means that the better the organizational climate, the better the organizational commitment at the Bali Provincial Inspectorate Office.

6. Organizational commitment mediate positively on the indirect effect of organizational justice on employee performance at the Bali Provincial Inspectorate Office. Based on these results, it can be stated that increasing organizational commitment will provide a boost to organizational justice in the workplace, and ultimately can improve employee performance at the Bali Provincial Inspectorate Office. The mediating effect of organizational commitment on this indirect effect is partial (full mediation). In other words, the implementation of organizational commitment can be said to be the main determinant of the indirect effect of organizational justice on employee performance.
Organizational commitment mediate positively on the indirect effect of organizational climate on employee performance at the Bali Provincial Inspectorate Office. Based on these results, it can be stated that increasing organizational commitment will provide a boost to the organizational climate in the workplace, and in the end can improve employee performance at the Bali Provincial Inspectorate Office. The mediating effect of organizational commitment on this indirect effect is partial (full mediation). In other words, the implementation of organizational climate can be said to be the main determinant of the indirect effect of organizational justice on employee performance.

\section{Suggestions}

Based on the limitations of the research stated above, the researcher hopes that this research can be useful as input. Some suggestions from researchers are as follows:

1. The results showed that the path of organizational commitment to employee performance had the greatest total effect, compared to the path of organizational justice and organizational climate on employee performance. Organizational commitment to the Bali Provincial Inspectorate Office has been going well, measured by several indicators, these should be maintained and improved.

2. So that superiors and employees at the Bali Provincial Inspectorate Office maintain cohesiveness in work and maintain and continue to improve existing cooperation or teamwork in order to optimize employee performance.

3. Organizational commitment is also very important in improving employee performance so that it is more optimal, an indicator that has a big influence is commitment to employees, so that if the organization is able to provide and pay attention to its employees well, willingness to serve the organization, a sense of pride as a member of the company will definitely be given. entirely by employees for organizational institutions.

\section{REFERENCES}

[1] Abdelaziz Swalhi et al (2017). The Influence Of Organizational Justice On Job Performance: The Mediating Effect Of Affective Commitment", Journal of Management Development, Vol. 36 Issue: 4, pp.542559.

[2] Allen and Meyer (2013). The Measurement And Antecedents Of Affective, Contintinuance And Normative Commitment To Organization,Journal of Occupational Psychology, Volume 63, Issue1, March 1990, Pages 1-18, PT. Elex Media Komputindo, Jakarta.

[3] Ari Radianto and Bambang Swasto Sunuharyo (2017). The Influence of Organizational Climate and Organizational Culture on Employee Performance (Study on Employees of PT.PG Krebet Baru Malang). Journal of Business Administration (JAB), Vol. 53 No. December 1, 2017.

[4] Bahadur Ali Soomro and Naimatullah Shah (2019). Determining The Impact Of Entrepreneurial Orientation And Organizational Culture On Job Satisfaction, Organizational Commitment, And Employee's Performance, South Asian Journal of Business Studies 
Vol. 8 No. 3, 2019 pp. 266-282, DOI 10.1108/SAJBS12-2018-0142.

[5] Colquitt et al (2009). Organization Behavior. McGrow Hill. International Edition.

[6] Dewi Nurcahyani and Fuad Mas'ud (2016). The Effect of Organizational Justice on Organizational Commitment with Power Distance as a Moderating Variable (Study At Pt. Pln (Persero) Apj Semarang), Diponegoro Journal Of Management, Volume 5, Number 3, 2016, ISSN (Online): 2337-3792.

[7] Cohen (1995). Quality Function Deployment: How to Make QFD Work for You. Adison Wesley Longman, Inc., Engineering Process Improvement Series, ISBN 0201-63330-2.

[8] Dharma and Agus (2014). Supervision Management. King Grafindo Persada. Jakarta

[9] Dua Nurak et al (2017). Examine The Effect Of Organizational Justice On Job Satisfaction And Employee Performance (June 5, 2017). Journal of Management and Marketing Review (JMMR) Vol. 2 (3) 2017. 30-37. Available at SSRN:https://ssrn.com/abstract=3009615.

[10] Ekawati Nugraha Dewi (2017). The Effect of Organizational Climate and Employee Competence on Employee Performance in Achieving Quality Health Services Outcomes, Public Journal, Vol. 11; No. 01; 2017; 89-100.

[11] Fauziah Noordin et al (2010). Organizational Climate And Its Influence On Organizational Commitment, International Business \& Economics Research Journal February 2010, Volume 9, Number 2. DOIhttps://doi.org/10.19030/iber.v9i2.516.

[12] Greenberg and J. \& Baron, RA (2007), Behavior in Organization. Prentice Hall (9 yrs.).

[13] Ghozali, I. (2009). Application of Multivariate Analysis With SPSS Program, printing IV BP UNDIP, Semarang.

[14] Gladys C. Kembuan et al (2018). The Effect Of Organization Climate, Career Development, Conflict, And Work Stress On Employee Performance Of Unsrat. EMBA Journal, Vol.6 No.3 July 2018, p. 1698 - 1707, ISSN 2303-1174.

[15] Hadi Purnama (2017). The Influence of Organizational Climate on Employee Performance at LP3I Polytechnic Jakarta, Cikarang Campus. Journal of Business Lantern, Vol. 6 No. 1, May 2017 / ISSN 2252-9993.

[16] Hasibuan and Malay SP (2016). Human Resource Management. Edition. Revision. Jakarta: Publisher PT. Earth Literature.

[17] Hussein Isse Hassan Abdirahman et al (2018). The Relationship Between Job Satisfaction, Work-Life Balance And Organizational Commitment On Employee Performance, Academic Journal of Economic Studies, Vol. 4, No. 3, September 2018, pp. 12-17 ISSN 2393-4913, ISSN On-line 2457-5836.

[18] Ismail Samreen et al (2018). Impact Of Organizational Justice And Organizational Citizenship Behavior On Employees Performance, International Journal of Human Resource Studies, Vol. 8, No.2, doi:10.5296/ijhrs.v8i2.13070.

URLs:https://doi.org/10.5296/ijhrs.v8i2.13070.
[19] Iqbal MZ et al (2017). The Impact Of Organizational Justice On Employee Performance In Public Sector Organization Of Pakistan. Int J Econ Manag Sci, Volume 6 Issue 3 1000431. doi: 10.4172/21626359.1000431.

[20] Kalay Faruk et al (2016). The Impact Of Organizational Justice On Employee Performance : A Survey In Turkey And Turkish Context, International Journal of Human Resource Studies, Vol. 6, No. 1, doi:10.5296/ijhrs.v6i1.8854 URL.

[21] Khuong Ngoc Mai and Quoc Hoang Thai (2016). The Effects Of Organizational Justice And Ethical Leadership On Employee Performance In Binh Duong's Industrial Parks, Vietnam. Journal of Economics, Business and Management, Vol. 4, No. 4, doi:10.18178/joebm.2016.4.4.412.

[22] Kristianto et al (2018). The Influence Of Leadership Style And Organizational Climate On Employee Performance Through Organizational Commitment, International Journal of Business and Applied Social Science (IJBASS), VOL: 4, ISSUE: 6 June 2018 http://ijbassnet.com/ E-ISSN: 2469- 6501.

[23] Mahmudi (2015). Public Sector Performance Management. Second Edition. Yogjakarta: UPP STIM YKPN.

[24] Mangkunegara A (2014). Company Human Resources Management. Bandung: Rosdakarya Youth.

[25] Mauludin Hanif and Sulistyorini Endang (2018). The Influences Of Transformational Leadership, Organizational Justice, Trust, And Organizational Commitment Toward Employee Performance, RJOAS, Vol. 10(82). DOIhttps://doi.org/10.18551/rjoas.201810.13 .

[26] Mehreen Fatima et al (2020). Organizational Justice And Employee Sustainability: The Mediating Role Of Organizational Commitment, SEISENSE Journal of Management, Vol 3 No 3 (2020): DOI: https://doi.org/10.33215/sjom.v3i3.334, 12-22.

[27] Muhammad Tahir et al (2019). The Influence Of Organizational Justice On Employee Organizational Commitment In The Information Technology Sector, Pakistan.Iqra Journal of Business \& Management (IJBM) Volume 1, Issue 1, 2019.

[28] Naomi W. Githinji and dr. Hazel Gachunga (2017). Influence Of Organizational Climate On Employee Performance In State Corporations In Kenya: A Case Of Kenya Industrial Estates Limited, EconomicsStrategic Journal of Business \& Change Management, Vol. 4, Iss. 2 (22), pp 376 - 395, May 16, 2017.

[29] Naiemah Ummi Saraih et al (2017). Relationships Between Organizational Commitment, OCB, Organizational Justice And Turnover Intention: Evidence From Educational Institution In Malaysia, Review of Integrative Business and Economics Research, Vol. 6, no. 2, pp.64-77, https://pdfs.semanticscholar.org/6a2c/acba06172d77e7 57aec2fce6c098c3cd210a.pdf.

[30] Putriana Lies (2015). The Impact Of Organizational Culture On Job Satisfaction, Organizational Commitment And Job Performance : Study On Japanese Motorcycle Companies In Indonesia, International Journal of Education and Research, Vol. 3 No. 9, 
http://www.ijern.com/journal/2015/September2015/09.

[31] Rivai (2014). Human Resource Management for Companies . 6th Edition, PT. Raha Grafindo Persada, Depok.

[32] Robbin, S. (2008). Organizational Behavior, Volumes I and II, Translated by: Hadyana Pujaatmaja. Jakarta: Prenhallindo.

[33] Robbins, SP and Judge TA (2015), Organizational Behavior. Jakarta: Four Salemba.

[34] Salih Zeki Imamoglu et al (2019). The Effect Of Organizational Justice And Organizational Commitment On Knowledge Sharing And Firm Performance, ScienceDirect, Procedia Computer Science 158 (2019) 899-906.

[35] Salim Musabah Bakhit Al Zefeiti and Noor Azmi Mohamad (2017). The Influence Of Organizational Commitment On Omani Public Employees' Work Performance. International Review of Management and Marketing, available at http: www.econjournals.com ,Vol 7, Issue 2, 151-160. ISSN: 2146-4405.

[36] Sedarmayadi (2014). Human Resources and Work Productivity. Jakarta: Forward Mandar.

[37] Suharto et al (2019). The Impact Of Organizational Commitment On Job Performance. International Journal of Economics \& Business Administration, Vol. 7, issue (2), 189 206.https://www.um.edu.mt/library/oar/handle/123456 789/44791.

[38] Sofiah Kadar Khan and Mohd Zabid Abdul Rashid, (2012).The Mediating Effect Of Organizational Commitment In The Organizational Culture, Leadership And Organizational Justice Relationship With Organizational Citizenship Behavior : A Study Of Academicians In Private Higher Learning Institutions In Malaysia. International Journal of Business and Social Science, Vol. 3 No. 8 [Special Issue - April 2012].

[39] Swalhi et al (2017). The Influence Of Organizational Justice On Job Performance: The Mediating Effect Of Affective Commitment, Journal of Management Development, Vol. 36 No. 4, pp. 542559.https://doi.org/10.1108/JMD-11-2015-0162.

[40] Tomy Fitrio et al (2020). The Rule Of Organizational Citizenship Behavior And Innovative Work Behavior In Mediating The Influence Of Organizational Commitment And Culture To Employee Performance, Growing Science, Canada, Accounting, 6 (2020) 13511360, doi: 10.5267/j.ac.2020.8.014.

[41] Wahyuni Daniati Sitorus (2016). The Effect of Organizational Climate and Organizational Commitment on Employee Performance (Study at Grand Zuri Hotel Pekanbaru). JOM FISIP, Vol. 4 No. October 2, 2017.

[42] Wang et al (2010). Procedural Justice, Participation And Power Distance Information Sharing In Chinese Firm. Emerald Insight Management Research Review, Vol. 33 No. 1, 66-78.

[43] Winarja, W., Sodikin, A., \& Widodo, DS (2018). The effect of Organizational Commitment and Job Pressure to Job Performance through the Job Satisfaction in Employees Directorate transformation Technology Communication and Information Indonesia.
International Journal of Business and Applied Social Science, VOL: 4, ISSUE: 2, 51-70. E-ISSN: 2469-6501, https://nbnresolving.org/urn:nbn:de:0168-ssoar-561905 . 